\title{
NUTRIENTS RETENTION IN FUNCTIONAL BEEF BURGERS WITH ESPECIAL EMPHASIS ON LIPID PROFILE
}

\author{
MC Romero ${ }^{1,2}$, AM Romero ${ }^{1}$, MM Doval ${ }^{1}$, MA Judis ${ }^{1}$ \\ ${ }^{1}$ Professor, Laboratory of Food Industry, Department of Basics and Applied Sciences, Chaco Austral National \\ University, Comandante Fernández, Chaco, Argentina. \\ ${ }^{2}$ Researcher, CONICET (Consejo Nacional de Investigaciones Científicas y Técnicas) Argentina.
}

\begin{abstract}
The true retention values of nutrients, with particular reference to fatty acids of dietary importance, were investigated in burgers with none or half of the pork backfat replaced with soybean oil -healthier burgers (HB)- added with $0 \mathrm{~g} / \mathrm{kg}, 5 \mathrm{~g} / \mathrm{kg}, 10 \mathrm{~g} / \mathrm{kg}$ and $20 \mathrm{~g} / \mathrm{kg}$ of dry soybean sprouts (DSS) as additive. A multivariate analysis was applied in order to detect the main fatty acids to characterize the finished product. Cooking yield of samples increased with the amount DSS incorporated, meaning that this bulking agent improved retention of water and fat in the matrix. The higher concentration of additive the higher the protein and total fat retention. Respect to fatty acid profile in samples incorporated with $5 \mathrm{~g} / \mathrm{kg}, 10 \mathrm{~g} / \mathrm{kg}$ of DSS the loss of fat -specially saturated fatty acids (SFA) - improved the ratio between polyunsaturated fatty acids (PUFA) and SFA. Also analyses of atherogenic and thrombogenic indices indicate that $10 \mathrm{~g} / \mathrm{kg}$ DSS presents the lower values for these parameters. Multivariate analysis shown that fatty acid descriptors with more contribution to variability of total data were miristic, palmitic, linoleic and linolenic fatty acid.
\end{abstract}

Keywords: Healthier burgers, Fatty acids, Nutrient retention, Multivariate analysis.

\section{INTRODUCTION}

The increasing concerns for health led the efforts made by the food industries to develop new foods with positive health benefits [1]. Meat is an exceptional source of appreciated nutrients such as high protein content and high iron contents which can help to prevent anemia that is a major health problem among adolescents especially girls [2]. However, as meat products due to its processing incorporate several additives -e.g. salt, nitrites, fats, bulking agents and synthetics antioxidants to improve mainly yield-, health authorities insist on recommending to reduce meat products consumption due to its high content of fat, specially saturated fatty acids (SFA) [3], [4].

The addition of $n 3$ polyunsaturated fatty acids (PUFA) to foods -e.g. adding soybean oil- is an emerging area of commercial and academic interest to improve composition of meat products, especially the fatty acid profile [5]. The manner that the oil is added in meat products is important because affects yield during cooking and generally, to reduce this loss some additives as soy protein concentrates or isolates are used [6], [7].

The usual approach of studying the effects that cooking process may have on nutrient contents of foods consists in distinguish what seems to have been the fate of each chemical component in terms of either an increase or a decrease, compared to its content at the raw state [8]. According to these authors the "true retention value of nutrient retentions" (TRVs) of products could provide a deeper insight into what cooking generated in the finished product. Consequently, the combination of experimental design using multivariate methods for comparison of results could be a powerful tool for improving the development of product. Moreover, as the composition of fatty acids depends on several factors -e.g. oil used in modified product, the way of adding different oils, product treatment or additives used-, the comparison of fatty acid profile using statistical methods for the examination of several variables could be a useful tool using a minimum number of experimental runs [9].

In a previous study, we found that incorporating different amounts of dry soybean sprouts (DSS) in meat patties elaborated with partial substitution of pork backfat with soybean oil to produce a healthier burger reduces cooking loss due to DSS's high protein, carbohydrate and fiber contents, having its bioactive components a technological benefit [10]. However, in that study we have not considered cooking effect on TRVs of nutrients in the modified products as in the quality of the fatty acid profile in the finished product. The same trend is observed in the majority of publications to date, which focus on the variations of nutrients and specially lipid content and fatty acid profiles in modified products, being TRVs a question that is often overlooked in food research and in the formulation of new products. Therefore, the objective of this study was to determine how cooking affects the true retention values of nutrients in healthier burgers with particular reference to fatty acids of nutritional importance, atherogenic and thrombogenic indexes of lipids also were evaluated. In addition, a multivariate analysis was applied to detect the main fatty acids to characterize the finished product. 


\section{MATERIALS AND METHODS}

\subsection{Material}

Dry soybean sprouts (DSS) were obtained from previously selected soybeans (Glycine $\max$ L. Merr, Munasqa, Tucumán, Argentina) [10].

Enriched beef patties were prepared using fresh lean meat and pork back fat obtained from local market. Soybean oil containing SFA $160 \mathrm{~g} / \mathrm{kg}$, MUFA $350 \mathrm{~g} / \mathrm{kg}$, PUFA $n 6$ $600 \mathrm{~g} / \mathrm{kg}$ and $n 3$ 6g/100g (Aceitera General Deheza S.A., Córdoba, Argentina) was used as pork back fat partial replacer.

\subsection{Burgers Preparation}

Five different formulations were elaborated as follows: one control sample (C) with $800 \mathrm{~g} / \mathrm{kg}$ beef and $200 \mathrm{~g} / \mathrm{kg}$ of pork backfat, and to obtain healthier burger (HB) four formulations by replacing the half of the pork backfat with soybean oil with the addition of $0 \mathrm{~g} / \mathrm{kg}, 5 \mathrm{~g} / \mathrm{kg}, 10 \mathrm{~g} / \mathrm{kg}$ and $20 \mathrm{~g} / \mathrm{kg}$ of DSS. The mixture was shaped manually using Petri-dish $(90 \mathrm{~mm} \quad \mathrm{x} 20 \mathrm{~mm})$ to obtain burgers of approximately $100 \mathrm{~g}$.

Initial and after cooking weight of two burgers of each formulation was registered to obtain the relevant cooking yield of the product $(\mathrm{CY})$. Cooking procedure was carried out in an electric oven $\left(200^{\circ} \mathrm{C}\right)$ until internal temperature reached $72^{\circ} \mathrm{C}$, samples were cooled at room temperature (20 $\left.{ }^{\circ} \mathrm{C}\right)$, placed in oxygen permeable bags $\left(2000 \mathrm{~cm}^{3} / \mathrm{m}^{2}\right.$ day) using a packing machine (RAPI-VAC S-750® SERVIVAC S.R.L., Buenos Aires, Argentina) and stored at $-18^{\circ} \mathrm{C}$ until analysis (within 30 days of preparation).

\subsection{Proximate Content and Fatty Acid Analysis}

With the purpose of obtain the true retention of nutrient in the cooked products the proximate composition and lipid profile determinate. The moisture, protein, fat and ash contents were analyzed in both raw and cooked products according to AOAC methods [11]. Total carbohydrates were quantified using Clegg anthrone methods [12] on an UV-Vis Beckman DU 640B® spectrophotometer (Fullerton, CA, United States). Total lipids were extracted by Bligh and Dyer method [13]. Boron trifluoride/methanol was used for the preparation of fatty acid methyl esters AOAC [11] and then they were analyzed using GC Mass Spectrometer (Thermo Fisher Scientific $®$, Austin, TX, USA) equipped with a $100 \%$ Cyanopropyl silicone capillary column (SPTM - $234060 \mathrm{~m}, 0.32 \mathrm{~mm}$ ID, film thickness $0.25 \mathrm{~mm}$ ). The oven temperature was held at $140^{\circ} \mathrm{C}$ for 5 minutes and subsequently increased at $4^{\circ} \mathrm{C} / \mathrm{min}$ to $220{ }^{\circ} \mathrm{C}$. Injector temperature was $250^{\circ} \mathrm{C}$. The injection volume was $1 \mu \mathrm{l}$. Identification of fatty acid methyl esters was based on retention time of standard esters (Supelco® 37 Components FAME Mixture, Bellefonte, PA) eluting from the capillary column. The fatty acid composition of total lipids was reported as $\mathrm{g} / 100 \mathrm{~g}$ of product.
In order to evaluate the risk of atherosclerosis and/or thrombogenesis, the atherogenic (AI) and thrombogenic indexes (TI) were calculated according to Ulbricht and Southgate [14] equations:

$$
\begin{gathered}
A I=\frac{(C 12: 0+4 \times C 14: 0+C 16: 0)}{(\text { (EMUFA }+ \text { IPUFA }+\Sigma n 3)} \\
T I=\frac{(C 14: 0+C 16: 0+C 18: 0)}{\left(0,5 \times \text { DPUFA } n 6+3 \times \text { LPUFA } n 3+\frac{n 3}{n 6}\right)}
\end{gathered}
$$

\subsection{True Nutrient Retention Values (TRVs) Calculation}

The TRV (\%) for each nutrient in the burgers was obtained using the following formula [6]:

$T R V(\%)=\frac{(\text { nutrient content per } g \text { of cooked food })}{(\text { nutrient content per } g \text { of raw product })} \times C Y$

This formula was fully applicable, in that, as mentioned before; initial weight in a raw control was register within each formulation.

\subsection{Statistical Analysis}

Data collected as mean \pm standard deviation were subjected to statistical analysis using the Statgraphics Plus 4.0 for Windows software package. In order to evaluate differences between TRVs of formulations a one-way analysis of variance (ANOVA) was used and Tukey test and Multiple Range Test was used for comparison of mean values to identify significant differences between samples $(p<0.05)$. Principal Component Analysis (PCA) and Discriminant Analysis (DA), using Statgraphics Plus were performed for characterize main fatty acids in the finished products. The experiment was replicated twice.

\section{RESULTS}

\subsection{Yield and True Nutrient Retention Value}

Composition of samples was affected by formulation and cooking, with interaction between the two factors $(p<0.05)$. Table 1 shows that cooking yield of samples increased with the amount DSS added, meaning that binding properties of this additive, may be related to the main dry soybean sprouts components, i.e. protein and fiber [10]. Yield of ground products varies widely depending on product formulation and processing conditions, but generally, this results agree with the reported by others authors in similar products [15], [16], [17].

The higher addition of DSS, the higher the moisture and fat retention in cooked burgers. Hence, due to DSS high carbohydrates and proteins contents [10], the effect of this additive on formulation was found to be significant, improving moisture and fat retention in samples after heat treatment enhancing the fat-absorption capacity [18]. The protein retention in the finished product indicate that protein 
content of cooked burgers was higher than the in raw samples. This same effect was observed by other authors [16], [19] owing to drip and leaching decreased moisture content and therefore increased protein content in cooked burgers. Yet, because protein is not susceptible to migration, due to coagulation/denaturation protein retention levels were above $100 \%$, this could be probably to the contribution to proteins contents of DSS.

Table -1: Mean values of cooking yield and true retention values of nutrients of healthier burgers (HB) formulated with partial replacement of pork back fat with soybean oil and different concentrations of DSS.

\begin{tabular}{|l|l|l|l|l|l|}
\hline \multirow{2}{*}{ TRVs } & $\mathrm{C}$ & $\mathrm{HB}$ & $\begin{array}{l}\mathrm{HB} \\
5 \mathrm{~g} / \mathrm{kg} \\
\text { DSS }\end{array}$ & $\begin{array}{l}\mathrm{HB} \\
10 \mathrm{~g} / \mathrm{kg} \\
\text { DSS }\end{array}$ & $\begin{array}{l}\mathrm{HB} \\
20 \mathrm{~g} / \mathrm{kg} \\
\text { DSS }\end{array}$ \\
\hline \multirow{2}{*}{ Yield } & $\begin{array}{l}72.22 \pm \\
0.03^{\mathrm{a}}\end{array}$ & $\begin{array}{l}74.40 \pm \\
0.25^{\mathrm{c}}\end{array}$ & $\begin{array}{l}72.96 \pm \\
0.13^{\mathrm{b}}\end{array}$ & $\begin{array}{l}77.43 \pm \\
0.09^{\mathrm{d}}\end{array}$ & $\begin{array}{l}79.33 \pm \\
0.07^{\mathrm{e}}\end{array}$ \\
\hline Moistu- & $67.82 \pm$ & $73.66 \pm$ & $73.58 \pm$ & $75.65 \pm$ & $77.45 \pm$ \\
re & $0.74^{\mathrm{a}}$ & $0.53^{\mathrm{b}}$ & $0.19^{\mathrm{b}}$ & $0.07^{\mathrm{c}}$ & $0.11^{\mathrm{d}}$ \\
\hline \multirow{2}{*}{ Total fat } & $49.59 \pm$ & $40.40 \pm$ & $40.08 \pm$ & $44.01 \pm$ & $70.70 \pm$ \\
& $0.02^{\mathrm{c}}$ & $0.29^{\mathrm{a}}$ & $0.17^{\mathrm{a}}$ & $0.57^{\mathrm{b}}$ & $0.01^{\mathrm{d}}$ \\
\hline \multirow{2}{*}{ Protein } & $97.22 \pm$ & 106.65 & 104.11 & 110.41 & 115.63 \\
& $0.77^{\mathrm{a}}$ & $\pm 0.01^{\mathrm{c}}$ & $\pm 0.54^{\mathrm{b}}$ & $\pm 0.60^{\mathrm{d}}$ & $\pm 0.47^{\mathrm{e}}$ \\
\hline Carbohy & $65.67 \pm$ & $86.93 \pm$ & $72.54 \pm$ & $71.72 \pm$ & $73.93 \pm$ \\
drates & $0.98^{\mathrm{a}}$ & $0.57^{\mathrm{c}}$ & $0.93^{\mathrm{b}}$ & $0.02^{\mathrm{b}}$ & $0.61^{\mathrm{b}}$ \\
\hline \multirow{2}{*}{ Ashes } & $52.94 \pm$ & $80.83 \pm$ & $78.37 \pm$ & $87.51 \pm$ & $94.41 \pm$ \\
& $0.45^{\mathrm{a}}$ & $0.86^{\mathrm{b}}$ & $1.07^{\mathrm{b}}$ & $1.07^{\mathrm{c}}$ & $2.21^{\mathrm{d}}$ \\
\hline
\end{tabular}

Results are presented as means \pm standard deviation of three replicates. Different letters $\left({ }^{\mathrm{a}}\right)$ in the same row denote significant differences among formulations $(\mathrm{p}<0.05)$.

\subsection{True Retention values of Fatty Acids Content}

In raw patties with soybean oil, linoleic acid (18:2 n6) emerged as the main fatty acid, followed by oleic acid (18:1 $\mathrm{n} 9)$ and palmitic acid (16:0). The cooking induced variations in fatty acid profile, and there was a noticeable loss of them in all samples. In the samples cooked the same fatty acid proportion of was observed too. Saturated fatty acid (SFA), mainly miristic and palmitic, were significantly reduced (around 22\%) after cooking in samples with $5 \mathrm{~g} / \mathrm{kg}$ and $10 \mathrm{~g} / \mathrm{kg}$ DSS.

Table 2 shows the true retention values determined in fatty acid profile of cooked patties with and without soybean oil and with and without dry soybean sprouts as additive. It can be observed that the all fatty acid retention was affected ( $\mathrm{p}<0.05)$. Firstly, although replacement of pork back fat by the soybean oil resulted in an improvement in the lipid profile, increasing the ratio unsaturated fatty acids/saturated fatty acids, when the samples were cooked the retention of unsaturated fatty acids was lesser, probably due to loss of them during the heat treatment. However, the addition of $20 \mathrm{~g} / \mathrm{kg}$ soybean sprouts improved unsaturated fatty acid retention, especially oleic, linoleic and linolenic acids (77\%, $73 \%$ and $70 \%$ respectively), but the saturated fatty acids were retained too. TRVs for fatty acids are lower than the reported by others researchers [16].
Fatty acid retention in products with $5 \mathrm{~g} / \mathrm{kg}$ and $10 \mathrm{~g} / \mathrm{kg}$ of DSS were minor for both saturated and unsaturated. However, the important loss of saturated improved the ratio between PUFA and SFA.

Regarding to nutritional aspects, SFA are known to increase low density lipoproteins (LDL) and hence blood cholesterol levels, whereas polyunsaturated fatty acids (PUFA) exhibit the opposite effect. AI and the TI were devised to show the effect of each fatty acid on human health [14]. AI assesses the risk of atherosclerosis and TI is an indicator of the potential aggregation of blood platelets, so very low values of AI and TI are recommended for a healthy diet. Table 2 show that HB $10 \mathrm{~g} / \mathrm{kg}$ DSS presents the lower values for these parameters. These values are near to those informed by some researchers [20].

Table -2: True retention values $(\%)$ of fatty acids in the analyzed samples

\begin{tabular}{|c|c|c|c|c|c|}
\hline $\begin{array}{l}\text { TRVs } \\
\text { of fatty } \\
\text { acids }\end{array}$ & $\mathrm{C}$ & HB & $\begin{array}{l}\mathrm{HB} \\
5 \mathrm{~g} / \mathrm{kg} \\
\mathrm{DSS}\end{array}$ & $\begin{array}{l}\text { HB } \\
10 \mathrm{~g} / \mathrm{k} \\
\mathrm{g} \\
\mathrm{DSS}\end{array}$ & $\begin{array}{l}\mathrm{HB} \\
20 \mathrm{~g} / \mathrm{kg} \\
\mathrm{DSS}\end{array}$ \\
\hline$(14: 0)$ & $\begin{array}{l}64.33 \pm \\
0.06^{\mathrm{b}}\end{array}$ & $\begin{array}{l}63.64 \pm \\
0.23^{\mathrm{b}}\end{array}$ & $\begin{array}{l}15.50 \\
\pm 0.21 \\
\mathrm{a}\end{array}$ & $\begin{array}{l}17.29 \\
\pm 0.41 \\
\mathrm{a}\end{array}$ & $\begin{array}{l}69.48 \pm \\
0.92^{\mathrm{c}}\end{array}$ \\
\hline$(16: 0)$ & $\begin{array}{l}61.44 \pm \\
0.13^{\mathrm{d}}\end{array}$ & $\begin{array}{l}55.31 \pm \\
0.70^{c}\end{array}$ & $\begin{array}{l}30.46 \\
\pm 0.09 \\
a\end{array}$ & $\begin{array}{l}37.15 \\
\pm 0.89 \\
\mathrm{~b}\end{array}$ & $\begin{array}{l}77.67 \pm \\
1.14^{\mathrm{e}}\end{array}$ \\
\hline$(16: 1)$ & $\begin{array}{l}63.17 \pm \\
0.13^{\mathrm{a}}\end{array}$ & $\begin{array}{l}66.70 \pm \\
1.03^{\mathrm{a}}\end{array}$ & $\begin{array}{l}85.79 \\
\pm 0.08 \\
c\end{array}$ & $\begin{array}{l}93.21 \\
\pm 2.33 \\
\mathrm{~d}\end{array}$ & $\begin{array}{l}74.28 \pm \\
1.91^{\mathrm{b}}\end{array}$ \\
\hline$(18: 0)$ & $\begin{array}{l}60.64 \pm \\
0.10^{d}\end{array}$ & $\begin{array}{l}54.08 \pm \\
0.69^{c}\end{array}$ & $\begin{array}{l}19.57 \\
\pm 0.03 \\
\mathrm{a}\end{array}$ & $\begin{array}{l}23.35 \\
\pm 0.55 \\
\mathrm{~b}\end{array}$ & $\begin{array}{l}76.30 \pm \\
1.14^{\mathrm{e}}\end{array}$ \\
\hline $\begin{array}{l}(18: 1) c \\
n 9\end{array}$ & $\begin{array}{l}62.01 \pm \\
0.12^{\mathrm{d}}\end{array}$ & $\begin{array}{l}56.09 \pm \\
0.73^{c}\end{array}$ & $\begin{array}{l}28.69 \\
\pm 0.07 \\
a\end{array}$ & $\begin{array}{l}34.37 \\
\pm 0.83 \\
\mathrm{~b}\end{array}$ & $\begin{array}{l}76.92 \pm \\
1.13^{\mathrm{e}}\end{array}$ \\
\hline $\begin{array}{l}(18: 2) c \\
n 6\end{array}$ & $\begin{array}{l}58.81 \pm \\
0.12^{d}\end{array}$ & $\begin{array}{l}39.82 \pm \\
0.51^{\mathrm{b}}\end{array}$ & $\begin{array}{l}32.01 \\
\pm 0.08 \\
\mathrm{a}\end{array}$ & $\begin{array}{l}46.17 \\
\pm 1.10 \\
\mathrm{c}\end{array}$ & $\begin{array}{l}72.81 \pm \\
1.09^{\mathrm{e}}\end{array}$ \\
\hline $\begin{array}{l}(18: 3) \\
n 3\end{array}$ & $\begin{array}{l}64.43 \pm \\
0.13^{\mathrm{d}}\end{array}$ & $\begin{array}{l}44.49 \pm \\
0.56^{\mathrm{c}}\end{array}$ & $\begin{array}{l}28.29 \\
\pm 0.09 \\
\mathrm{a}\end{array}$ & $\begin{array}{l}40.72 \\
\pm 1.00 \\
\mathrm{~b}\end{array}$ & $\begin{array}{l}70.16 \pm \\
1.05^{\mathrm{e}}\end{array}$ \\
\hline$(20: 2) c$ & $\begin{array}{l}65.07 \pm \\
0.26^{\mathrm{b}}\end{array}$ & $\begin{array}{l}97.13 \pm \\
1.70^{\mathrm{d}}\end{array}$ & N.D. ${ }^{a}$ & N.D. ${ }^{a}$ & $\begin{array}{l}80.42 \pm \\
1.18^{\mathrm{c}} \\
\end{array}$ \\
\hline AI & $\begin{array}{l}0.89 \pm 8 \\
.53 \mathrm{E}- \\
04^{\mathrm{e}}\end{array}$ & $\begin{array}{l}1.01 \pm 0 \\
.01^{\mathrm{d}}\end{array}$ & $\begin{array}{l}0.53 \pm \\
4.77 \mathrm{E} \\
-03^{\mathrm{b}}\end{array}$ & $\begin{array}{l}0.50 \pm \\
2.49 \mathrm{E} \\
-04^{\mathrm{a}}\end{array}$ & $\begin{array}{l}0.75 \pm 3 \\
.08 \mathrm{E}- \\
03^{\mathrm{c}}\end{array}$ \\
\hline TI & $\begin{array}{l}0.54 \pm 3 \\
.13 \mathrm{E}- \\
04^{\mathrm{c}}\end{array}$ & $\begin{array}{l}0.65 \pm 2 \\
.96 \mathrm{E}- \\
03^{\mathrm{d}}\end{array}$ & $\begin{array}{l}0.41 \pm \\
1.27 \mathrm{E} \\
-03^{\mathrm{b}} \\
\end{array}$ & $\begin{array}{l}0.37 \pm \\
1.76 \mathrm{E} \\
-04^{\mathrm{a}} \\
\end{array}$ & $\begin{array}{l}0.54 \pm 1 \\
.17 \mathrm{E}- \\
03^{\mathrm{c}} \\
\end{array}$ \\
\hline
\end{tabular}

Results are presented as means \pm standard deviation of three replicates. Different letters $\left({ }^{\mathrm{a}}\right)$ in the same column denote significant differences among formulations $(p<0.05)$. N.D.: not detected. 


\subsection{Multivariate Analysis}

PCA provides a first evaluation of the discriminating efficiency of the selected features and a visualization of the sample trends. The two first Principal Components (PCs) explain about $91.216 \%$ of the total variation for fatty acid content. PC1 explains $78.802 \%$ and is characterized by two fatty acids (C14:0 and $\mathrm{C} 18: 3 \mathrm{n3})$; while the PC2 explains $12.414 \%$ and is characterized by two fatty acids too (C16:0 and C18:2 n6).

Discriminant analysis was applied to the data in order to obtain suitable classification rules for the samples. Figure 1 shows variable-variable plots of all the combinations of these descriptors displaying the complete separation of the samples A detailed examination of the variable loadings of PC1 shows that the descriptors with more contribution were 14:0 and 18:3, n3. The graphics show it is possible to discriminate between samples considered in this study. As can be observed samples control, healthier burger with soybean oil, with $20 \mathrm{~g} / \mathrm{kg}$ of dry soybean sprout presented the highest content of SFA C14:0 and, although samples with $20 \mathrm{~g} / \mathrm{kg}$ DSS retain more PUFA 18:3 $n 3$ than other two. Healthier burgers with $5 \mathrm{~g} / \mathrm{kg}$ and $10 \mathrm{~g} / \mathrm{kg}$ of DSS also are differentiated by $\mathrm{C} 14: 0$ and $\mathrm{C} 18: 3 \mathrm{n3}$ contents, showing that both samples retained lower amount of C14:0, but samples with $10 \mathrm{~g} / \mathrm{kg}$ retained higher amount of C18:3 n3.
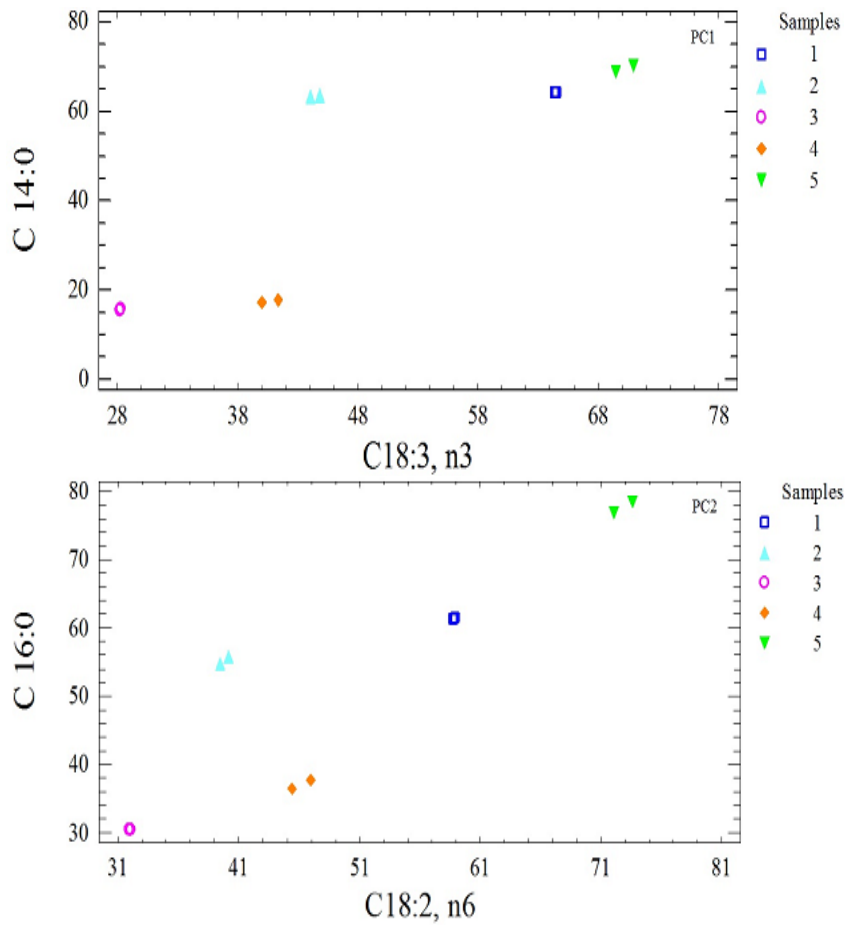

Fig -1: Scores plot for the two PCs. PC1 is characterized by $\mathrm{C} 14: 0$ and $\mathrm{C} 18: 3 n 3$, and $\mathrm{PC} 2$ by $\mathrm{C} 16: 0$ and $\mathrm{C} 18: 2, n 6$. Samples: 1: control, 2: HB, 3: HB 5g/kg DSS, 4: HB: $10 \mathrm{~g} / \mathrm{kg}$ DSS, 5: HB 20g/kg DSS.

Three discriminant functions were obtained, being the equation for the first DF the following:

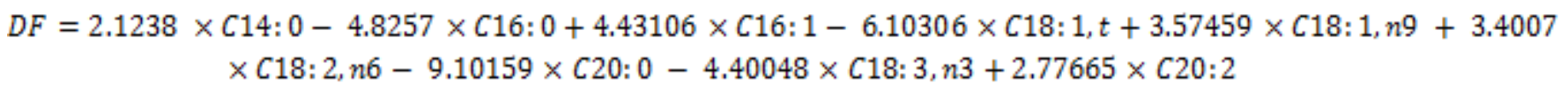

Analyses of discriminant functions shown five different groups of samples, corresponding to all analyzed samples.

\section{CONCLUSION}

Results show that the addition of dry soybean sprouts in healthier burgers increase the retention values of fat, proteins and carbohydrates in cooked patties, being this effect directly related with the concentration of DSS in samples. Cooking affected the fat and fatty acid contents in the finished product, but through the soya sprouts addition was possible to improve the fatty acid profile of the final product. Concentration of $10 \mathrm{~g} / \mathrm{kg}$ of DSS in the burgers is the best formulation for retain the fatty acids of high nutritional value, improving AI and TI. The descriptors with more contribution to variability of total data were miristic, palmitic, linoleic and linolenic fatty acids. Differences between samples were corroborated through PCA and DA analyses. Yet, more research needs to be conducted to develop a healthier burger containing $10 \mathrm{~g} / \mathrm{kg}$ of dry soybean sprouts with better cooking properties.

\section{ACKNOWLEDGEMENTS}

This research was supported by Universidad Nacional de Chaco Austral, and Consejo Nacional de Investigaciones Científicas y Tecnológicas (CONICET), Argentina.

\section{REFERENCES}

[1]. Mallika E.N., Prabhakar K. and Reddy P.M. 2009. Low Fat Meat Products - An Overview. Veterinary World, 2, 9, 364-366.

[2]. Miah Md.S., Rahman M.N., Prodhan U.K., Linkon, M.R., Madumita and Rahman Md.S. 2014. International Journal of Research in Engineering and Technology, 3, 6, 613-619.

[3]. World Cancer Research Fund/American Institute for Cancer Research. 2007. Food, nutrition and the prevention of cancer: A global perspective. Washington, DC: A.I.C.R

[4]. World Cancer Research Fund/American Institute for Cancer Research Policy and action for cancer prevention. 2009. Food, nutrition, and physical activity: A global perspective Washington, DC.

[5]. Fernández D.L., Sturla M.A., Doval M.M., Romero A.M. and Judis M.A. 2013. Inhibition of Lipid Oxidation by 
MRP Antioxidant in Enriched Cooked Beef Patties with Polyunsaturated Fatty Acids. Journal of Food Research, 1, 3, 128-137.

[6]. Cengiz E. and Gokoglu N. 2007 Effects of fat reduction and fat replacer addition on some quality characteristics of frankfurter-type sausages. International Journal of Food Science and Technology, 42, 3, 366-372.

[7]. Valencia I., Ansorena D. and Astiasaran I. 2006 Stability of linseed oil and antioxidants containing dry fermented sausages: A study of the lipid fraction during different storage conditions. Meat Science, 73, 2, 269-277.

[8]. Badiani A., Stipa S., Bitossi F., Pirini M., Bonaldo A., Gatta P.P., Rotolo M. and Testi S. 2013. True retention of nutrients upon household cooking of farmed portion-size European sea bass (Dicentrarchus labrax L.). LWT - Food Science and Technology, 50, 72-77.

[9]. Arvanitoyannis I. S., Bloukas J.G., Pappa I. and Psomiadou E. 2000. Multivariate data analysis of Cavourmas - A Greek cooked meat product. Meat Science, 54, 71-75.

[10]. Romero M.C., Garro O.A., Romero A.M., Doval M.M. and Judis M.A. 2014 Evaluation of the addition of dry soybean sprouts on cooking yield and oxidative stability of enriched beef patties with soybeans oil. The Journal of Food Technology, Photon, 106, 227-238.

[11]. AOAC Association of Official Analytical Chemist. 1990. 15th Edition, Washington DC.

[12]. Clegg, K.M. 1956. The Application of the Anthrone Reagent to the Estimation of Starch in Cereals. Journal of the Science of Food and Agriculture, 7, 40-44

[13]. Bligh, E. and Dyer, W. 1959. A Rapid Method of Total Lipid Extraction and Purification. Canadian Journal of Biochemistry and Physiology, 37, 911-917.

[14]. Ulbricht T.L.V. and Southgate D.A.T. 1991. Coronary heart -disease- 7 dietary factors. Lancet, 338, 8773, 985-992.

[15]. Hur S.J., Jin S.K. and Kim I.S. 2008. Effect of extra virgin olive oil substitution for fat on quality of pork patty. Journal of Science Food and Agriculture, 88, 7, 1231-1237. [16]. López-López I., Cofrades S., Cañeque V., Díaz M.T., López O. and Jiménez-Colmenero F. 2011 Effect of cooking on the chemical composition of low-salt, low-fat Wakame/olive oil added beef patties with special reference to fatty acid content. Meat Science, 89, 27-34.

[17]. Jung E. and Joo N. 2013 Roselle (Hibiscus sabdariffa $L$.) and soybean oil effects on quality characteristics of pork patties studied by response surface methodology. Meat Science, 94, 391-401).

[18]. Ali R.F.M., El-Anany A.M., Gaafar A.M. 2011. Effect of Potato Flakes as Fat Replacer on the Quality Attributes of Low-Fat Beef Patties. Advance Journal of Food Science and Technology, 3, 3, 173- 180.

[19]. Alakali J.S., Irtwange S.V., Mzer M.T., 2010. Quality evaluation of beef patties formulated with Bambara groundnut (Vigna subterranean L.) seed flour. Meat Science, 85, 215-223.

[20]. Rosa R, Bandarra NM, Nunes ML. 2007 Nutritional quality of African catfish Clarias gariepinus (Burchell 1822): a positive criterion for the future development of the
European production of Siluroidei. International Journal of Food Science and Technology, 42, 342-351. 